\title{
Article
}

\section{The Mycorrizal Status in Vineyards Affected by Esca}

\author{
Lucia Landi, Renzo Foglia, Sergio Murolo (D) and Gianfranco Romanazzi *(D)
}

Citation: Landi, L.; Foglia, R.; Murolo, S.; Romanazzi, G. The Mycorrizal Status in Vineyards Affected by Esca. J. Fungi 2021, 7, 869 https://doi.org/10.3390/jof7100869

Academic Editors: David Gramaje and Ales Eichmeier

Received: 28 August 2021

Accepted: 12 October 2021

Published: 16 October 2021

Publisher's Note: MDPI stays neutral with regard to jurisdictional claims in published maps and institutional affiliations.

Copyright: (c) 2021 by the authors. Licensee MDPI, Basel, Switzerland. This article is an open access article distributed under the terms and conditions of the Creative Commons Attribution (CC BY) license (https:// creativecommons.org/licenses/by/ $4.0 /)$.
Department of Agricultural, Food and Environmental Sciences, Marche Polytechnic University, Via Brecce Bianche, I-60131 Ancona, Italy; 1.landi@univpm.it (L.L.); r.foglia@univpm.it (R.F.); s.murolo@univpm.it (S.M.)

* Correspondence: g.romanazzi@univpm.it

\begin{abstract}
In this work we analyzed the relationship among native arbuscular mycorrhizal fungi $(\mathrm{AMF})$ and vine roots affected by esca, a serious grapevine trunk disease. The AMF symbiosis was analyzed on the roots of neighboring plants (symptomatic and asymptomatic to esca) in 14 sites of three vineyards in Marche region (central-eastern Italy). The AMF colonization intensity, identified by nonvital staining, showed higher value in all esca symptomatic plants (ranging from $24.6 \%$ to $61.3 \%$ ) than neighboring asymptomatic plants (from $17.4 \%$ to $57.6 \%$ ). The same trend of Glomeromycota phylum abundance was detected by analyzing fungal operational taxonomic units (OTUs) linked to the AMF community, obtained by amplicon high throughput analysis of ITS 1 region. Overall, the highest amount of OTUs was detected on roots from symptomatic plants $(0.42 \%)$, compared to asymptomatic roots $(0.29 \%)$. Specific primer pairs for native Rhizophagus irregularis and Funneliformis mosseae AMF species, were designed in 28S rRNA and large subunit (LSU) ribosomal RNA, respectively, and droplet digital PCR protocol for absolute quantification was set up. A higher number of DNA copies of both fungal species were detected more frequently in symptomatic than asymptomatic vines. Our study suggests a relationship between esca and native AMF in grapevine. These results underline the importance of native rhizosphere microbial communities for a better knowledge of grapevine esca disease.
\end{abstract}

Keywords: droplet digital PCR; esca; grapevine roots; mycorrhizal non-vital staining; native AMF; operational taxonomic units (OTUs)

\section{Introduction}

Esca, together with Eutypa dieback and Botryosphaeria dieback, are considered the most destructive trunk diseases of grapevine, and are a rapidly growing concern in all wine producing countries [1]. This disease involves several xylem-inhabiting fungi [2-7]. The general symptoms are expressed on the one hand at the foliar level by discoloration and drying and on the other hand at wood level through sectorial necrosis with the presence of brown streaking or cankers [8]. Characteristic symptoms of grapevines affected by these diseases are sunken necrotic root lesions with a reduction in root biomass and root hairs [9]. As a result, the symptoms produced by esca are detrimental to the resilience of the wine-growing heritage [1]. Since the trunk disease's pathogens are mainly soilborne [1,10], a helpful role in plant health management may be played by rhizosphere microorganisms, such as mycorrhizal fungi. Arbuscular mycorrhizal fungi (AMF, phylum Glomeromycota, class Glomeromycetes) [11], are the most common obligate biotrophic symbiotic fungi associated with plant species. More than $80 \%$ of plant species in natural conditions are mycorrhized. This exceptionally ancient ( $>450$ million years) and coevolutionary relationship is considered the key factor in early plant colonization of land and has also been verified to be generally beneficial to both partners [11,12]. The AMF are completely dependent on their host's carbon source, then, as mutual exchange, the plant receives additional nutrients and improved water relations [12-14]. Furthermore, in addition to this nutritional function, AMF field and pot inoculation can enhance plant tolerance to both biotic and abiotic stresses including drought, salinity, herbivory, temperature, metals, 
and diseases, relative to their non-mycorrhizal counterparts in experimental studies [15]. Several mechanisms whereby AMF could cause pathogen protection are known, including changes in root architecture, improvement of nutrient status, competition for infection sites or activation of plant defence mechanisms, including the upregulation of the antioxidant system, modifications in the phytohormone profile and secondary metabolites [16-18]. This multifunctional ability of the partner fungi has led to the development and applications of mycorrhizal inoculants as biofertilizers in agriculture. Mycorrhizal inoculation has been applied for decades to promote better plant growth for various crop plants [19]. Several studies point out the higher efficiency of native AMF inoculum, starting from native soils as an alternative to commercial formulates [20-23]. A different role could be played by the nontarget native mycorrhiza, naturally present in the soil. The native AMF which forms multispecies symbiont communities in the same host root, are well adapted to the local environment [24]. Various agricultural management practices modify the native AM fungal community qualitatively and quantitatively [25]; however, there is not enough information about the relationship of mycorrhizal native species, already established in the plant, and plant diseases. Concerning the grapevine plants, they are remarkably dependent on mycorrhizae, since this plant has low-density roots and few root hairs. In vineyards, the AMF communities mainly belong to the Glomerales order, phylum Glomeromycota $[26,27]$. They are highly influenced by the soil characteristics but also, to a smaller extent, by the host plant development stage and cultivars [28,29]. Concerning the AMF external inoculum effect on trunk disease, different results were observed, as there was an increase in tolerance to grapevine disease [30], but an enhancement of in the number of pathogens present was also observed [31]. Additionally, although the key role of AMF in plant productivity and ecosystem is undisputed [27,32], different relationships among mycorrhizal and pathogens detected on plants, underline the complexity of plant-AMF-pathogen interactions relationship [33,34]. Until now, the relationship between native AMF community and esca diseases was unexplored. Therefore, to establish the impacts that esca has on the whole beneficial AMF-plant symbiosis, one of the primary approaches is to quantify the total AMF colonization on roots from asymptomatic or symptomatic grapevines. Usually, nonvital staining of mycorrhizal colonization [35], followed by microscopic investigation, has provided reliable data on the degree of root colonization. This is an easy and fast method for analyzing the whole root's mycorrhizal status, including the presence and distribution of key features such as arbuscules, processing a large number of samples but without discriminating the AMF species [33,36]. Recently, the omics approach has allowed researchers to quantify the abundance of mycorrhiza in both plant roots and soil $[17,37,38]$. For high throughput sequencing, the operational taxonomic units (OTUs) technique was used in several works according to rRNA (SSU rRNA) [39], or internal transcribed spacer (ITS) region, this last as universal barcode for fungi marker genes clustered into OTUs according to nucleotides' similarity [40]. For species-specific detection and absolute quantification of single sequence, the droplet digital PCR (ddPCR) is widely used. This method is now often used as alternative to quantitative real-time PCR (qPCR) [41]. Recently, it was also applied for Rhizophagus irregularis copy number quantification [32]. ddPCR s based on the amplification of single target DNA molecules in many separate droplets (water-in-oil emulsion) resulting in a positive-negative call for every droplet and greater amenability to multiplexed detection of target molecules [42]. With respect to qPCR, ddPCR offers the advantage of direct and independent quantification of DNA without standard curves and reduction of numbers of technical replicates [43].

The goal of this work was to investigate the relationships among of AMF native root symbionts and esca disease. To achieve this aim, several approaches were used: (i) evaluating total AMF colonization using non-vital Trypan blue (TB) staining; (ii) analyzing the global abundance of Glomeromycota phylum according the OTUs with ITS primers; (iii) developing and validating the ddPCR identification and quantification of $R$. irregularis and Funneliformis mosseae selected as marker species in the vineyard soils among Glomerales order. 


\section{Materials and Methods}

\subsection{Experimental Trials}

The experiment was performed from January to July 2017 in the three commercial vineyards, located in Ancona district, Marche region, in central-eastern Italy. In detail:

Vyn_1-The vineyard, located in Castelplanio (AN), 43 $50^{\prime} 30^{\prime \prime} \mathrm{N}-13^{\circ} 09^{\prime} 50.3^{\prime \prime} \mathrm{E}$, was planted in 2004. The grape cultivar was 'Verdicchio' grafted onto Kober 5BB (Vitis berlandieri $\times V$. riparia) rootstock. The soil has a medium texture tending to be melted, with a scarce amount of organic matter. The morphology of the land is hilly, and the exposure of the vineyard is south/west. The roots of the selected vine plants were collected in January.

Vyn_2-The vineyard, located in San Biagio of Osimo (AN), site at $43^{\circ} 31^{\prime} 09^{\prime \prime} \mathrm{N}$ $13^{\circ} 28^{\prime} 47^{\prime \prime} \mathrm{E}$ at 463 meters above sea level (m a.s.l.), was planted in 2002. The grape cultivar was 'Verdicchio' grafted onto Kober 5BB rootstock. The soil has a medium texture tending to clay, fresh, fertile, deep and mainly grassy. The roots from the selected grapevine plants were collected in May.

Vyn_3-The vineyard, located in Osimo (AN), site at $43^{\circ} 29^{\prime} 81^{\prime \prime} \mathrm{N}-13^{\circ} 26^{\prime} 12.83^{\prime \prime}$ E, at (m a.s.l.) was planted in 2002. The grape cultivar was 'Chardonnay', grafted onto Kober $5 \mathrm{BB}$ rootstock. The vineyard is exposed to the south/east. The soil has a medium texture, with a high organic substance. Usually, the soil is ploughed both in the row and along the rows, with elimination of any infesting flora. The roots from the selected grapevine plants were taken in July.

The investigated vineyards were not irrigated, the fertilizers were distributed in winter, and an additional green pruning was applied in spring and summer, as are the normal practices for the area. In all vineyards, an integrated pest management program was applied to control the main fungal diseases (downy mildew, powdery mildew, gray mold) and pests (moths).

\subsection{Collected Samples}

In each vineyard, fourteen sites were randomly selected. From each site, one symptomatic plant (I) and the neighboring asymptomatic plant (A) were selected for the study (Supplementary Figure S1). In detail, four plants for the vineyards Vyn_1 (plants A1, I1; A2, I2; A3, I3; A4, I4 from sites 1, 2, 3 and 4, respectively) and Vyn_2, (plants A5, I5; A6, I6; A7, I7 and A8, I8 from sites 5, 6, 7 and 8, respectively) and six for vineyard Vyn_3 (plants A9, I9; A10, I10; A11, I11; A12, I12; A13, I13 and A14, I14; from sites 9, 10, 11, 12, 13 and 14). A total of 28 plants were analyzed: 14 plants showing "leaf tiger-stripes" (symptomatic vines) and 14 asymptomatic plants. From each plant, the roots were collected at a depth of about $20 \mathrm{~cm}$. A portion of the terminal root system from each plant was randomly selected and washed with tap water. A total of 8-10 g from each plant were collected, half of which were stored in acetic acid:ethanol (50:50) solution for total non-vital staining. Half of the roots were stored at $-20^{\circ} \mathrm{C}$ for the following DNA extraction.

\subsection{Total Native AMF Assessment Using Non-Vital Staining and Light Microscopy}

For assessing the total AMF symbiosis, from each plant, secondary roots were collected from different points of plant's roots system. Then, 50 sections of $1 \mathrm{~cm}$-long pieces were randomly chosen and analyzed by non-vital staining with Trypan Blue (TB) [44]. After clearing the root samples in $10 \% \mathrm{KOH}$ solution for $20 \mathrm{~min}$ at $80{ }^{\circ} \mathrm{C}$, the roots were stained with $0.05 \%(w / v)$ TB in lactoglycerol (lactic acid:glycerol: $\left.\mathrm{H}_{2} \mathrm{O}, 1: 1: 1, v / v / v\right)$ for $20 \mathrm{~min}$ at $80^{\circ} \mathrm{C}$. Stained roots were observed with a light microscope, Nikon Eclipse E600 microscope (Nikon, Tokyo, Japan). The degree of mycorrhizal colonization of each root segment and the abundance of arbuscules were estimated as described by Trouvelot et al. [45]. In detail, 5 classes described the percentage of AMF colonization intensity $0=0 \% ; 1 \leq 1 \% ; 2 \leq 10 \%$; $3 \geq 11 \%<50 \% ; 4 \geq 51 \%<90 \% ; 5 \geq 91 \%$. To estimate the abundance of arbuscules, 4 different classes were used: $\mathrm{A} 0=0$; $\mathrm{A} 1=$ few arbuscules, (from $\mathrm{N}^{\circ} 0$ to $\mathrm{N}^{\circ} 5$ for root segments); $\mathrm{A} 2$ = frequent (from $\mathrm{N}^{\circ} 6$ to $\mathrm{N}^{\circ} 20$ for root segments); $\mathrm{A} 3=$ abundant ( $>$ of $\mathrm{N}^{\circ} 20$ ). The MYCOCALC software was used to calculate the frequency of mycorrhiza in the root 
system $(\mathrm{F} \%)$, colonization intensity $(\mathrm{M} \%)$ and abundance of arbuscules $(\mathrm{A} \%)$ parameters using the following equations: $\mathrm{F} \%=\left(\mathrm{l}_{\mathrm{m}} / \mathrm{l}_{\mathrm{t}}\right) * 100 ; \mathrm{M} \%=\left(95 \mathrm{n}_{5}+70 \mathrm{n}_{4}+30 \mathrm{n}_{3}+5 \mathrm{n}_{2}+\mathrm{n}_{1}\right) / \mathrm{l}_{\mathrm{t}}$; $\mathrm{A} \%=\mathrm{a} \% * 0.01 \mathrm{M} \%$. Where: $\mathrm{l}_{\mathrm{m}}$ is the total number of root segments in which mycelium were found; $l_{t}$ is the total number of the examined segments; $n_{5}-n_{1}$ is the total number of root segments in which the degree of colonization intensity by mycorrhizal structures was $5-1,(\mathrm{n} 5=$ number of fragments rated $5 ; \mathrm{n} 4=$ number of fragments 4, etc.); $\mathrm{a} \%$ is related to absolute abundance of arbuscules for the segments in which arbuscules were present (for more details: https://www2.dijon.inrae.fr/mychintec/Mycocalc-prg/download.html, accessed 15 September 2021).

\subsection{Molecular AMF Native Detection and Quantification \\ 2.4.1. DNA Extraction}

For each sample, two subsamples were obtained. From each subsample, $2 \mathrm{~g}$ of pooled roots ground in liquid nitrogen, then $200 \mathrm{mg}$ of pulverized tissues were collected and put in $2 \mathrm{~mL}$ microcentrifuge tube for total DNA extraction. The CTAB (cetyl trimethyl ammonium bromide) procedure [46] modified by Landi et al. [47] was used. DNA purity and quantity were estimated by BioPhotometer plus (Eppendorf Inc., Westbury, NY, USA). Preliminary test to detect two of the main pathogens linked to esca as Phaeomoniella chlamydospora and Phaeoacremonium ultimum, performed by PCR [48], was confirmed only on symptomatic plants (data not shown).

\subsubsection{Overall Quantification of Glomeromycota with High-Coverage ITS Primers}

Total DNA extracted from all asymptomatic and symptomatic root samples, was amplified in total volume $25 \mu \mathrm{L}$ using the primer pair ITS1F_KYO2 (5'TAGAGGAAGTAAAAGTC GTAA $\left.3^{\prime}\right)$ and ITS2_KYO2 (5'TTYRCTRCGTTCTTCATC $\left.3^{\prime}\right)$ [49], able to amplify the ITS 1 region. PCR was conducted using under a temperature profile of $94^{\circ} \mathrm{C}$ for $4 \mathrm{~min}$, followed by 35 cycles at $94{ }^{\circ} \mathrm{C}$ for $30 \mathrm{~s}, 56{ }^{\circ} \mathrm{C}$ for $30 \mathrm{~s}$, and $72{ }^{\circ} \mathrm{C}$ for $20 \mathrm{~s}$, followed by $72{ }^{\circ} \mathrm{C}$ for $7 \mathrm{~min}$. The concentration of $\mathrm{MgCl}_{2}$, dNTPs, PCR primers and the template DNA in the reaction buffer were $1.5 \mathrm{mM}, 200 \mathrm{mM}, 0.5 \mathrm{mM}$ and $1 \mathrm{ng} / \mu \mathrm{L}$, respectively. The amplified samples were checked on agarose gel, then the amplicons of asymptomatic and symptomatic samples were, respectively (or separately) pooled, obtaining two different samples. The two samples were purified using Wizard ${ }^{\circledR}$ SV Gel and the PCR Clean-Up System (Promega Madison, WI, USA), then quantified with the Biophotometer (Eppendorf), in order to estimate the threshold of quantity $(60 \mathrm{ng} / \mu \mathrm{L}$; at least $500 \mathrm{ng})$ and quality $(260 / 280>1.8$; and at $260 / 230$ in range of 1.7 ).

\subsubsection{DNA Sequencing and Bioinformatics Analysis}

Fungal ITS1 amplicon pools related to symptomatic and asymptomatic plants were sent to GENEWIZ, Inc. (South Plainfield, NJ, USA), which provided library preparations, Illumina MiSeq sequencing and data analysis according to the manufacturer's instructions of GENEWIZ Amplicon-EZ technology. Sequences were grouped into operational taxonomic units (OTUs) using the clustering program VSEARCH (1.9.6) against the UNITE ITS database (https: / / unite.ut.ee/; accessed 15 September 2021) pre-clustered at $97 \%$ sequence identity. The Ribosomal Database Program (RDP) classifier was used to assign taxonomic category to all OTUs at confidence threshold of 0.8. The RDP classifier uses the UNITE ITS database, which has taxonomic categories predicted to the species level.

\subsection{Rhizophagus Irregularis and Funneliformis Mosseae Absolute Quantification}

\subsubsection{Primer Selections and Validation}

Specific primers were selected according to $28 \mathrm{~S}$ rRNA and large subunit (LSU) ribosomal RNA genes for R. irregularis (National Center for Biotechnology Information, NCBI cod. HF968988.1) and F. mosseae (NCBI cod. FN377865.1), respectively, using Primer3web version 4.1.0. (http://bioinfo.ut.ee/primer3-0.4.0/, accessed 15 September 2021). The primers named RI/f (5'-GGCGTTATTGTCGCACCTAT3'), and RI/r (5'- 
CCTTGGTTTTTCAAGGGTCA-3'), that amplify a 248 bp PCR fragment, were developed for $R$. irregularis species and primers named FM/f ( $5^{\prime}$-CCTATGGATCCCCCTTTTGT3 $\left.{ }^{\prime}\right)$ and $\mathrm{FM} / \mathrm{r}\left(5^{\prime}\right.$-AGATGCTGCAGAAGGCAAAT3'), that amplify a $190 \mathrm{bp}$ PCR fragment, were developed for $F$. mosseae species.

\subsection{2. qPCR Assay}

Before using the primers in ddPCR technology, for absolute quantification of $R$. irregularis and F. mosseae in the root samples, their ability and specificity to detect the species present in the root samples was validated according to GPCR protocol followed by amplicon sequencing analysis. The qPCR analysis was performed according the Landi et al. [47] protocols using the primers pair RI/f- RI/r and FM/f-FM/r.

To validate the homology with the AMF species, the sequence analysis of qPCR amplicons obtained from RI/f-r, primers by I1 and A5 plant roots (named S1_V1 and S5_V2 samples) and FM V/f-r primers by I4 and A10 plant roots (named S4_V1 and S10_V3 samples) were performed. The fragments were sequenced by Genewiz (Hope End, Takeley, UK) and subjected to bioinformatic analysis. Sequence similarity searches were performed using Blast analysis in NCBI.

After sequencing and qPCR validation, a serial dilution of qPCR fragments amplified from root samples generating a qPCR standard curve was performed. Both the limits of detection (LOD) estimated from analysis of number of positive replicates, [50], and possible inhibitors of the root's matrix, were estimated. In detail, four-point ten-fold serial dilution of R. irregularis qPCR fragment S1_V1 (from $3.5 \times 10^{-8}$ to $3.5 \times 10^{-11} \mathrm{ng} /$ reaction) and F. mosseae, qPCR fragment S10_V3 (from $2.8 \times 10^{-8}$ to $2.8 \times 10^{-11} \mathrm{ng} /$ reaction) were amplified alone or spiked with DNA from Quercus ilex, holm oak, AMF nonhost roots (50 ng, and $5 \mathrm{ng} /$ reaction). In addition, several dilutions (100, 50, 5, 0.5 ng) of DNA from roots of esca symptomatic plant I10 and asymptomatic plant A7 were also analyzed (the analysis of these samples was carried out after mixing the DNA of the two respective subsamples). DNA from grapevine leaf tissue was included as negative control. The same sample dilutions were tested in the ddPCR setup, with the exception of the spiked with $5 \mathrm{ng} /$ reaction of DNA from holm oak.

\subsection{3. ddPCR Assay}

The ddPCR assay was performed using QX200 Droplet Digital PCR system (Bio-Rad Laboratories, Hercules, CA, USA). With the aim to setup and validate the ddPCR assay, serial dilution of both, $R$. irregularis and F. mosseae 28SRNA PCR fragment alone or combined with DNA from AMF holm oak nonhost roots, and of the I10 and A7 grapevine roots samples, previously described and analyzed on qPCR assay, were tested. The analysis was carried out in $20 \mu \mathrm{L}$ of reaction mixture including $1 \times$ QX200 ddPCR EvaGreen supermix (Bio-Rad), 0.3 or $0.5 \mu \mathrm{M}$ each primer. Each $20 \mu \mathrm{L}$ reaction mixture was transferred into the DG8 cartridge. Next, Droplet Generation Oil (Bio-Rad) was added to the cartridge which was placed into the QX200 Droplet Generator ${ }^{\mathrm{TM}}$ (Bio-Rad). After droplet generation, the mixtures were carefully transferred to a ddPCR ${ }^{\mathrm{TM}}$ 96-well PCR plate (Bio-Rad) after which the plate was sealed at $180^{\circ} \mathrm{C}$ using PX1 ${ }^{\mathrm{TM}} \mathrm{PCR}$ plate sealer (Bio-Rad). The amplification was performed in the thermal cycler, ICycler (Bio-Rad), with a ramp rate of $2{ }^{\circ} \mathrm{C} / \mathrm{s}$ with the following protocol: $95{ }^{\circ} \mathrm{C}$ for $5 \mathrm{~min}$ followed by 40 cycles of denaturation at $95^{\circ} \mathrm{C}$ for $30 \mathrm{~s}$ and $58{ }^{\circ} \mathrm{C}$ for $1 \mathrm{~min}$. The enzyme was deactivated at $4{ }^{\circ} \mathrm{C}$ for $5 \mathrm{~min}$ followed by $90^{\circ} \mathrm{C}$ for $5 \mathrm{~min}$. Droplets were read in a QX200 Droplet reader (Bio-Rad) after which the ddPCR data were analyzed using QuantaSoft Version 1.6.6. The script analyzed the data of the signals exported from the QuantaSoft software, with its automatic threshold defined or with a selected, manually defined, threshold applied. This incorporates the calculation of the basic parameters of the ddPCR (i.e., concentration, mean amplitudes of positive and negative droplets); the mean copies per partition and the total volume of the partitions measured, as defined by the digital MIQE guidelines [51]. Two positive droplets were enough to determine a sample as positive, and only the reactions with more than 
10,000 accepted droplets were used for analysis. After protocols setup, $50 \mathrm{ng}$ of DNA from symptomatic and asymptomatic root samples were analyzed using $0.3 \mu \mathrm{M}$ each primer.

\subsection{Statistical Analysis}

Data sets according to AMF colonization of symptomatic and asymptomatic plants, detected by non-vital staining, were analyzed according to Student's paired $t$-test. Differences were considered significant when $p<0.01$. The same data sets were tested for correlations using the Pearson's coefficient (r) $p<0.05$. The difference among AMF symbiosis in the esca symptomatic and asymptomatic plants according to the vineyards were statistically analyzed (Vyn_1, $n=4$; Vyn_2, $n=4$; Vyn_3 $n=6$ ). The arcsin square root transformation was used to normalize the percentage ratios data prior to statistical analysis. The data set of AMF colonization was subjected to one-way ANOVA for mean comparisons, standard deviation (SD) and significant differences calculated according to Duncan's Multiple Range Test, $p<0.05$.

For qPCR set-up using I10 and A7 root samples and spiked samples (see Table 1 and Supplementary Tables S1-S3) (three replicates in three independent experiments, $\mathrm{n}=9$ ); and ddPCR set-up (mixed subsample in two independent experiments, $n=2$ ) the SD was performed. Linear regression analysis in ddPCR investigation between copies of target genes/ng of root DNA, or ng of qPCR amplicon were analyzed using Excel 2010. Data sets according to ddPCR absolute quantification of target genes by R. irregularis and F. mosseae for each plant were statistically analyzed (two independent experiments for each subsample, $n=4$ ). Data set of ddPCR absolute quantification was subjected to oneway ANOVA for mean comparisons, standard deviation (SD) and significant differences calculated according to Duncan's Multiple Range Test, $p<0.05$.

Table 1. The qPCR inhibitors and limits of quantification estimated by qPCR standard curve. DNA of AMF nonhost roots from oak plants (0,5 and $50 \mathrm{ng} / \mathrm{qPCR}$ reaction) spiked with serial dilutions AMF qPCR fragments (S1_V1 sample, for $R$. irregularis, S10_V3 sample and F. mosseae, respectively). The experiments were assessed in triplicate over three independent experiments $(n=9)$. Cq, quantification cycle; SD, standard deviation; na, not amplified. *, four replicates amplified of nine performed.

\begin{tabular}{|c|c|c|c|c|}
\hline & \multicolumn{4}{|c|}{ qPCR } \\
\hline & \multirow{3}{*}{$\begin{array}{c}\text { AMF qPCR Fragments } \\
\text { from Grapevine Roots } \\
\text { (ng/reaction) + }\end{array}$} & \multicolumn{3}{|c|}{ DNA from Oak Nonhost Plant } \\
\hline & & $0 \mathrm{ng}$ & $5 \mathrm{ng}$ & $50 \mathrm{ng}$ \\
\hline & & \multicolumn{3}{|c|}{ Cq mean $\pm \mathrm{SD}$} \\
\hline \multirow{4}{*}{ R. irregularis } & $3.5 \times 10^{-8}$ & $22.3 \pm 0.12$ & $22.9 \pm 0.2$ & na \\
\hline & $3.5 \times 10^{-9}$ & $25.7 \pm 0.16$ & $25.9 \pm 0.2$ & na \\
\hline & $3.5 \times 10^{-10}$ & $29.4 \pm 0.3$ & $30.6 \pm 0.3$ & na \\
\hline & $3.5 \times 10^{-11}$ & $31.6 \pm 1.1^{*}$ & $32.1 \pm 1.7 *$ & na \\
\hline \multirow{5}{*}{ F. mosseae } & $2.8 \times 10^{-8}$ & $23.8 \pm 0.12$ & $23.8 \pm 0.12$ & na \\
\hline & $2.8 \times 10^{-9}$ & $27.4 \pm 0.19$ & $27.2 \pm 0.19$ & na \\
\hline & $2.8 \times 10^{-10}$ & $31.5 \pm 0.9$ & $32.8 \pm 1.3$ & na \\
\hline & $2.8 \times 10^{-11}$ & $32.8 \pm 1.7 *$ & $33.6 \pm 2.1 *$ & na \\
\hline & \multicolumn{4}{|c|}{ Statistics of standard curve performance, mean \pm SD } \\
\hline \multirow{4}{*}{ R. irregularis } & Slope & $3.155 \pm 0.02$ & $3.162 \pm 0.03$ & na \\
\hline & Efficiency & $107.1 \pm 0.74$ & $109.7 \pm 0.99$ & na \\
\hline & Y-intercept & $1.078 \pm 0.04$ & $3.97 \pm 0.02$ & na \\
\hline & Value of fit (R2) & $0.99 \pm 0.001$ & $0.98 \pm 0.002$ & na \\
\hline
\end{tabular}


Table 1. Cont.

\begin{tabular}{|c|c|c|c|c|}
\hline & & \multicolumn{3}{|c|}{ qPCR } \\
\hline & & \multicolumn{3}{|c|}{ DNA from Oak Nonhost Plant } \\
\hline & \multirow{2}{*}{$\begin{array}{c}\text { AMF qPCR Fragments } \\
\text { from Grapevine Roots } \\
\text { (ng/reaction) + }\end{array}$} & 0 ng & $5 \mathrm{ng}$ & $50 \mathrm{ng}$ \\
\hline & & \multicolumn{3}{|c|}{ Cq mean $\pm \mathrm{SD}$} \\
\hline \multirow{4}{*}{ F. mosseae } & Slope & $3.117 \pm 0.02$ & $3.092 \pm 0.02$ & na \\
\hline & Efficiency & $109.3 \pm 0.87$ & $111.7 \pm 1.01$ & na \\
\hline & Y-intercept & $2.723 \pm 0.12$ & $2.495 \pm 0.31$ & na \\
\hline & Value of fit (R2) & $0.98 \pm 0.001$ & $0.99 \pm 0.002$ & na \\
\hline
\end{tabular}

\section{Results}

\subsection{Total Native AMF Assessment Using Non-Vital Staining and Light Microscopy}

Related to non-vital staining, native AMF colonization was detected in all analyzed root samples of both esca symptomatic and asymptomatic plants with a frequency (F\%) of around of $100 \%$. Relating to each of the 14 sites identified in the vineyards, all the esca symptomatic plants showed higher significative native mycorrhizal colonization related to both mycelium colonization (M\%) $(p<0.0001$, Student's paired $t$-test) and arbuscular abundance $(\mathrm{A} \%),(p=0.0005$, Student's paired $t$-test $)$ than the neighboring asymptomatic plants (Figure $1 \mathrm{a}, \mathrm{b}$ ). In the symptomatic, plants the $\mathrm{M} \%$ ranged from $24.6 \%$, detected in the symptomatic plant I4, to $61.3 \%$, in I14; while in the asymptomatic plants the $\mathrm{M} \%$ ranged from 17.4\%, detected in A12, to 57.6\%, detected in A14 (Figure 1a). The A\% abundance in symptomatic plants ranged from $8.1 \%$, related to plant I1, to $38.9 \%$, detected in plant I8, while in asymptomatic plants the $\mathrm{A} \%$ ranged from $5.7 \%$, in $\mathrm{A} 1$, to $25.8 \%$ in plant A14 (Figure 1b).

Positive correlation among esca symptomatic and asymptomatic plants of both AMF mycelium colonization (Figure 2a) and arbuscular abundance was detected (Figure 2b).

The average mycorrhization value of the plants analyzed for each vineyard was also analyzed. For each vineyard, the average M\% ranged from 30.3\% (Vyn_1) to 48.4\% (Vyn_2) (Figure 3a), while the A\% ranged from 14.5\% (Vyn_1) to 21.6\% (Vyn_2) (Figure 3b). In the asymptomatic plants, the $\mathrm{M} \%$ value ranged from $22.8 \%$ (Vyn_1) to 40.5\% (Vyn_2) (Figure 3a), while the A\% value ranged from 10.5\% (Vyn_1) to 15.8\% (Vyn_2) (Figure 3b). The Vyn_3 showed intermediate values. Not significant differences in native mycorrhizal infection were recorded between asymptomatic and symptomatic plants in each vineyard.

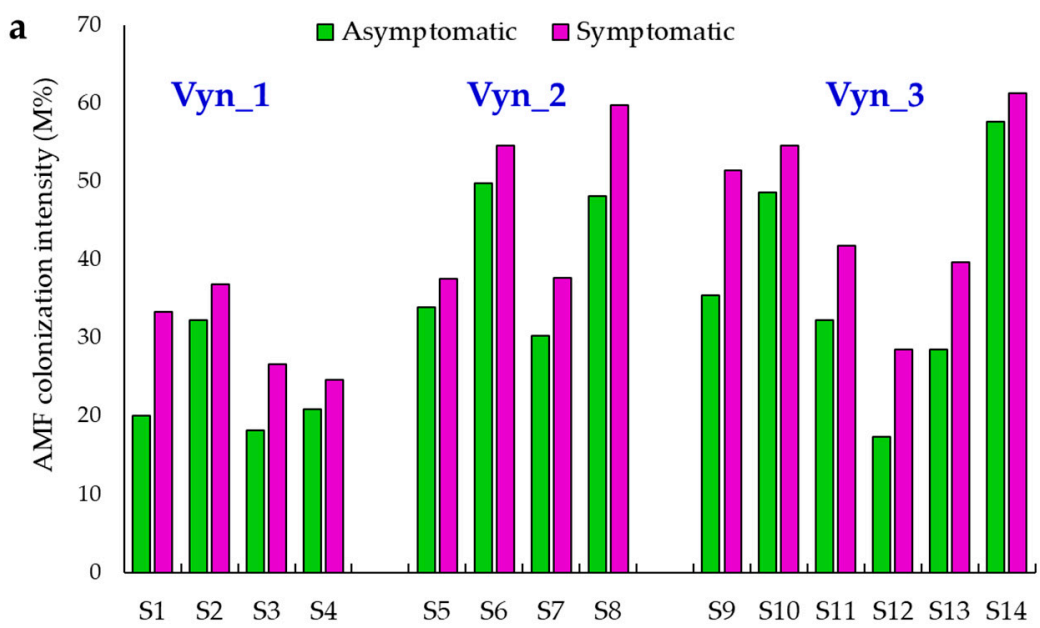

Figure 1. Cont. 


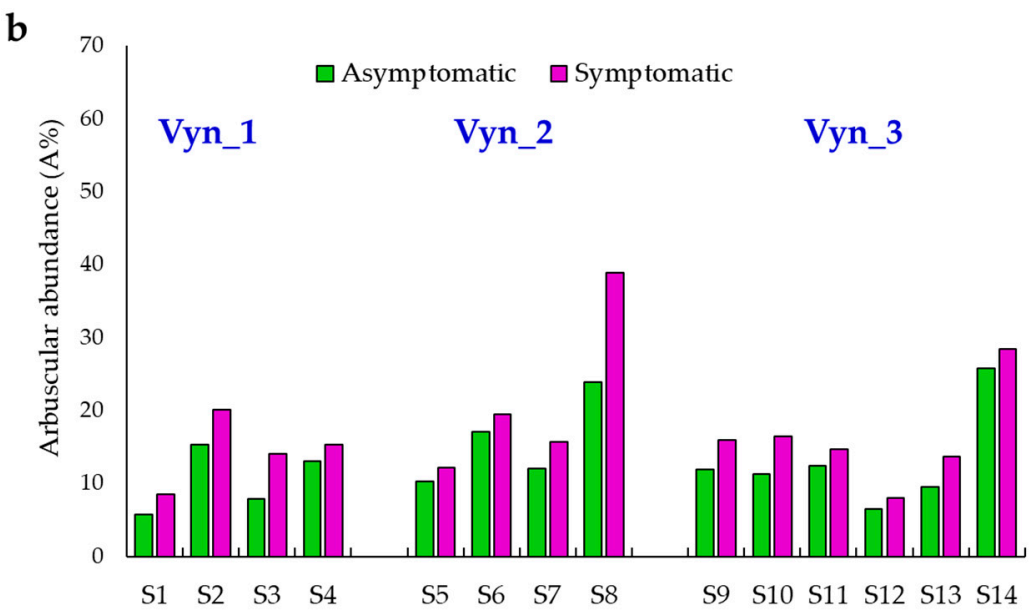

Figure 1. AMF mycelium colonization (M\%), (a), and arbuscular abundance (A\%) (b), detected by non-vital staining from each asymptomatic and contiguous esca symptomatic plants from each site (S) individuate in the vineyards (Vyn_1, Vyn_2 and Vyn_3).

a

AMF colonization intensity (M\%) Symptomatic $=11.447+0.90442 *$ Asymptomatic

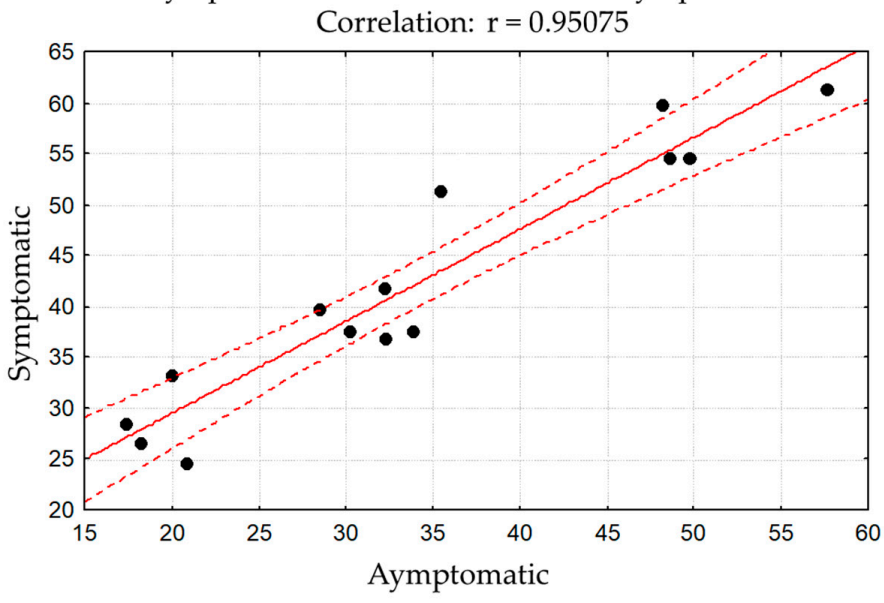

b

Arbuscular abundance (A\%)

Symptomatic $=0.86086+1.2571 *$ Asymptomatic

Correlation: $\mathrm{r}=0.92501$

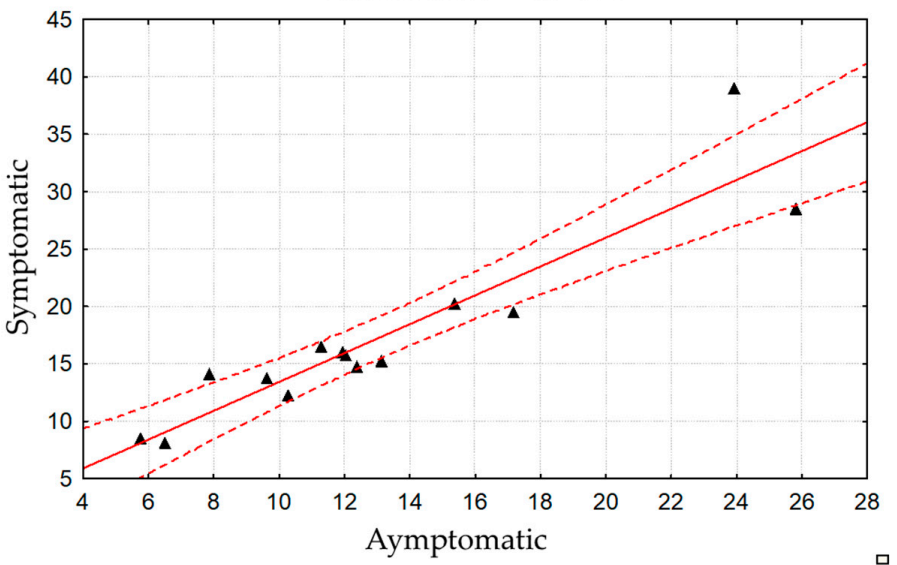

Figure 2. Correlation related to AMF mycelium colonization (a) and arbuscular abundance (b) detected by non-vital staining in asymptomatic and nearby esca symptomatic plants. Pearson's coefficient $(\mathrm{r}) p<0.05$. 


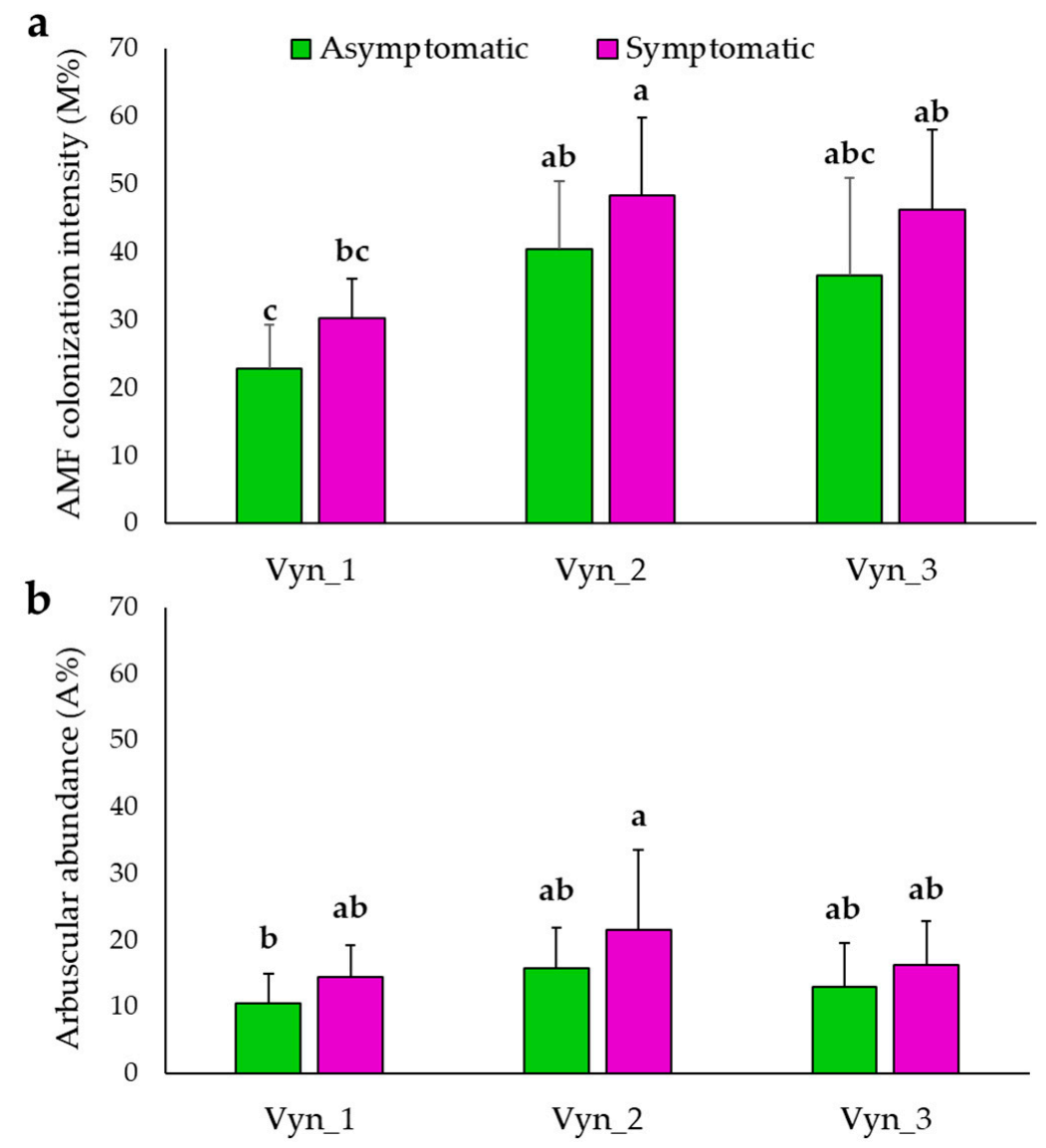

Figure 3. AMF mycelium colonization (\% M) (a) and arbuscular abundance (\% A) (b) detected by non-vital staining of roots of esca symptomatic and asymptomatic grapevine plants collected in three different vineyards (Vyn_1, Vyn_2 and Vyn_3). For each trait, means followed by at least one common letter are not significantly different, according to Duncan's Multiple Range Test $(p<0.05)$. The data were normalized according to the arcsine square root.

\subsection{Overall Quantification of Glomeromycota with High-Coverage ITS Primers}

A total of 66,352 quality reads were obtained from asymptomatic and symptomatic pool samples, grouped into 241 OTUs for taxonomic affiliation with Ascomycota, Basidiomycota, Cercozoa, and Glomeromycota, at phylum level. Other different OTUs sequences generically assigned to fungi kingdom were also detected (Figure 4a). From the bioinformatic analysis, 275 sequences detected in roots from symptomatic plants, and 193 sequences, detected in roots from asymptomatic plants, have been assigned to three OTUs defined as phylum Glomeromycota (Figure 4b).

\subsection{Rhizophagus Irregularis and Funneliformis Mosseae Absolute Quantification \\ 3.3.1. Primer Selection and Validation}

The qPCR analysis showed a singular amplicon of $81.5^{\circ} \mathrm{C}$ melting temperatures (TM), according to primers RI/f-r, specific for $R$. irregularis, while the primers $\mathrm{FM} / \mathrm{f}-\mathrm{r}$, amplify for a singular amplicon of $80.5^{\circ} \mathrm{C} \mathrm{TM}$, specific for F. mosseae. Sequence analysis of the PCR amplicons indicated as isolates S1_V1 (NCBI accession number MK513942) and S5_V3 (MK513943) were homologous to $>98 \%$ of the reference sequences related to $28 \mathrm{~S}$ rRNA gene of $R$. irregularis, NCBI accession number HF968988.1, and FJ235574.1. In detail, for $R$. irregularis primers, we identified a 248-bp that included the nucleotide substitutions of $\mathrm{A} \rightarrow \mathrm{G} ; \mathrm{G} \rightarrow \mathrm{A} ; \mathrm{G} \rightarrow \mathrm{C} ; \mathrm{A} \rightarrow \mathrm{G}$; (positions 81; 136; 140; 185; MK513942 and MK513943/ HF968988.1, and FJ235574.1, respectively). Blast analysis of the nucleotide sequences indicated as isolates S4_V1 (MK513940) and S10_V3 (MK513941) revealed a high nucleotide 
identity with the reference sequences related to the LSU gene of $F$. mosseae (of $98.94 \%$ with FN377862.2; 98.42\% with FN377865.1) The F. mosseae primers identified a 190-bp that included the nucleotide substitutions of $A \rightarrow C$ (position 68; MK513940 and MK513941/ FN377865.1); CT $\rightarrow$ GC (positions 116-117; MK513940 and MK513941/FN377865.1 and FN377865.1) (Supplementary Figure S2).

a

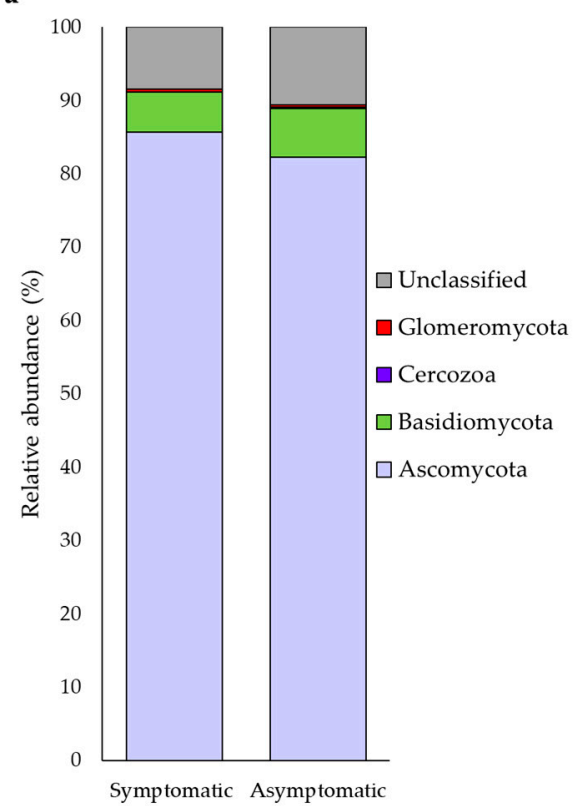

b

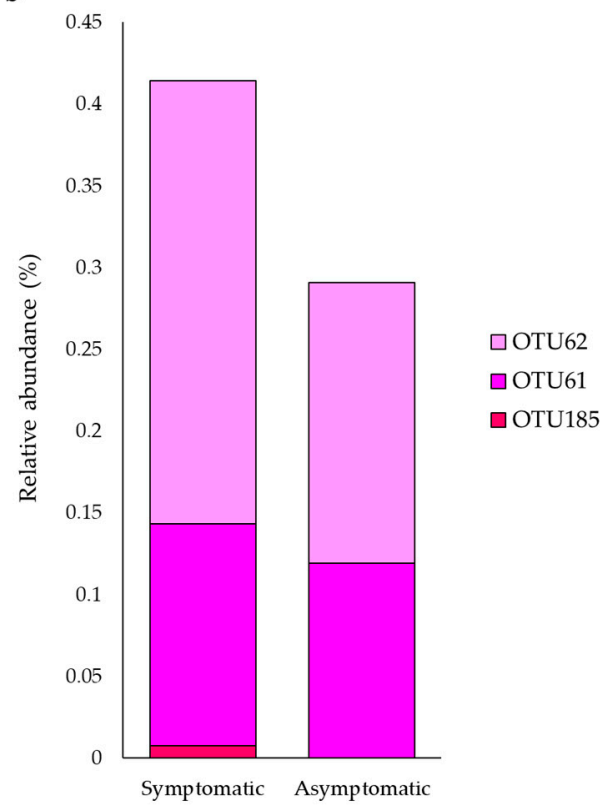

Figure 4. Phylum composition of the fungal community (a) and change in abundance of OTU assigned to Glomeromycota phylum (b) related to AMF, associated with pool of DNA from asymptomatic and symptomatic grapevine to esca.

\subsection{2. qPCR Assay}

The analysis of the nine replicates of 28SRNA S1_V1 qPCR of target fragments used as template, for the four dilutions used to generate the standard curve on $R$. irregularis ranging from $22.3+0.12$ quantification Cycle $(\mathrm{Cq})$ for the $3.5 \times 10^{-8} \mathrm{ng} /$ reaction, to $31.6 \pm 1.1 \mathrm{Cq}$ for the $3.5 \times 10^{-11} \mathrm{ng} /$ reaction. Really, the probability of replicates' detection of the last dilution was lower than $95 \%$, underlining the limit of detection of the gene (Table 1). Similar results were detected for $F$. mosseae. The four tested dilutions related to the LSU gene of the S10_V3 qPCR fragment, ranging from $23.8 \pm 0.12 \mathrm{Cq}\left(2.8 \times 10^{-8} \mathrm{ng} /\right.$ reaction $)$, to $32.8 \pm 0.6 \mathrm{Cq}\left(2.8 \times 10^{-11} \mathrm{ng} /\right.$ reaction $)$ (Table 1$)$. The qPCR of both $R$. irregularis and $F$. mosseae serial dilution of target fragments spiked with DNA roots of oak nonhost plants of $\mathrm{AMF}$, at concentrations $50 \mathrm{ng} /$ reaction, was inhibited, while the addition of $5 \mathrm{ng} /$ reaction of DNA from nonhost root showed no inhibition of the PCR amplification (Table 1).

The analyses of four-point serial dilutions related to I10 and A7 grapevine samples root indicate a total inhibition of qPCR amplification testing 100 and $50 \mathrm{ng}$ DNA/reaction for both species, while a positive sample was detected at 5 and $0.5 \mathrm{ng}$ DNA/reaction but not for all replicates (Supplementary Table S1).

\subsection{3. ddPCR Assay}

The amount of the droplets was >of 15,000 in $72 \%$ of the analyzed samples, and in the range $10,000-15,000$ in the $28 \%$ for the remainder. Samples relative to the four 10 -fold dilutions of 28SRNA and LSU qPCR fragment (analyzed alone or spiked with $50 \mathrm{ng}$ of DNA from nonhost root) showed a good degree of linearity $(R 2>0.996)$ in the range of about 8 to 2940 copies $/ 20 \mu \mathrm{L} / \mathrm{PCR}$ reaction for $R$. irregularis species and about 5 to 3020 copies $/ 20 \mu \mathrm{L} / \mathrm{PCR}$ reaction for F. mosseae (Figure 5d-f; Supplementary Table S2). No ddPCR inhibition was detected related to nonhost DNA added to the reaction. 
a

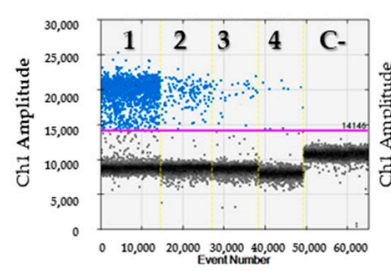

d

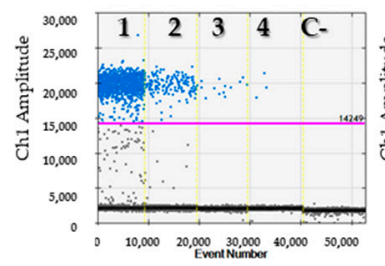

b

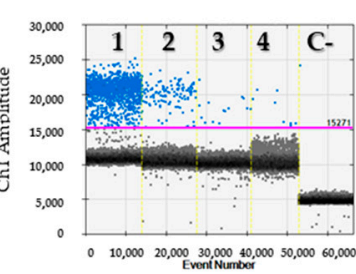

e

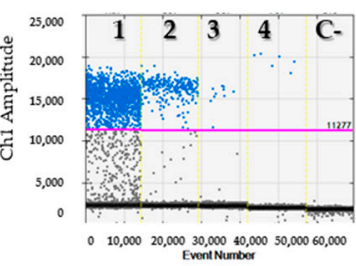

C

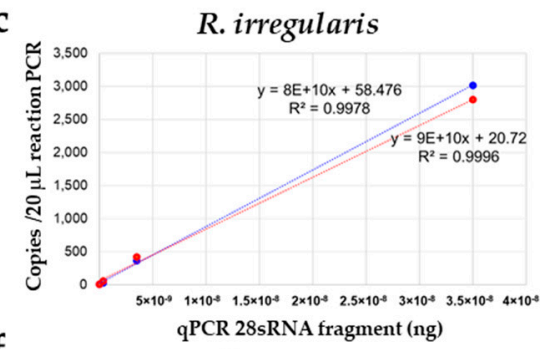

F. mosseae

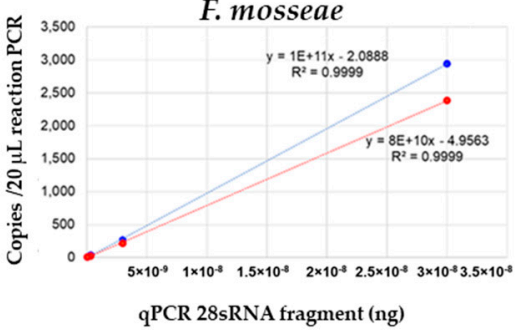

Figure 5. Performance of primer sets with various serially diluted targets in ddPCR. (a,b,d,e), The ordinate scales indicate fluorescent amplitude. The pink line is the threshold, above which are positive droplets (blue) containing at least one copy of target DNA and below which are negative droplets (gray) without any target DNA. Samples are divided by the vertical dotted yellow line. (a) Ten-fold serial dilutions of $R$. irregularis S1_V1 qPCR fragment (from $3.5 \times 10^{-8}$ to $3.5 \times 10^{-11} \mathrm{ng} /$ reaction); (b) $50 \mathrm{ng} /$ reaction of AMF nonhost DNA from Quercus ilex, oak spiked with ten-fold serial dilutions of S1_V1 qPCR fragment; (c) linear regression of serial dilutions analyzed in (a) (blue line) and (b) (red line); (d) ten-fold serial dilutions of F. mosseae S10_V3 qPCR fragment (from $2.8 \times 10^{-8}$ to $2.8 \times 10^{-11} \mathrm{ng} /$ reaction); (e) $50 \mathrm{ng} /$ reaction of AMF nonhost DNA from Quercus ilex L., oak, spiked with ten-fold serial dilutions of S10_V3 qPCR fragment; (f) linear regression of serial dilutions analyzed in (d) (blue line) and (e) (red line). C- = negative control.

In the same way, a ten-fold serial dilution performed according to the DNA from I10 and A7 roots grapevine samples showed a good degree of linearity, (R2 > 0.996) for both $R$. irregularis and F. mosseae, with detection from 50 to $0.5 \mathrm{ng}$ DNA of roots/reaction, while the amounts of DNA from roots per reaction showed saturation reached at $100 \mathrm{ng}$ of DNA (Figure 6a,b). In the sample I10, from 50 to $0.5 \mathrm{ng}$ DNA of roots/reaction, the quantity of $R$. irregularis target gene ranging from about 706 to 9 copies $/ 20 \mu \mathrm{L} / \mathrm{PCR}$, while the F. mosseae target gene ranged from 36 to 1.4 copies $/ 20 \mu \mathrm{L} / \mathrm{PCR}$. In sample A7, the quantity of $R$. irregularis target genes ranged from about 105 to 2.2 copies $/ 20 \mu \mathrm{L} / \mathrm{PCR}$, and the F. mosseae target gene from 50 to 1.2 copies $/ 20 \mu \mathrm{L} / \mathrm{PCR}$ (Supplementary Table S3). No amplification was observed according to DNA from grapevine leaf tissue (data not shown).

a

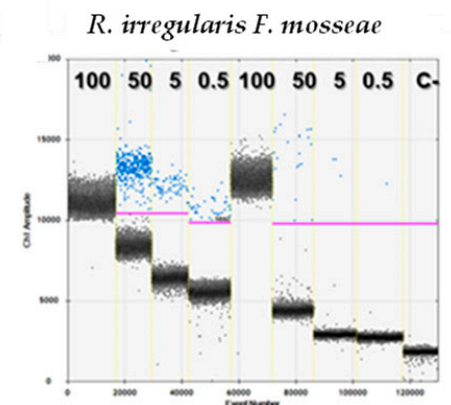

b

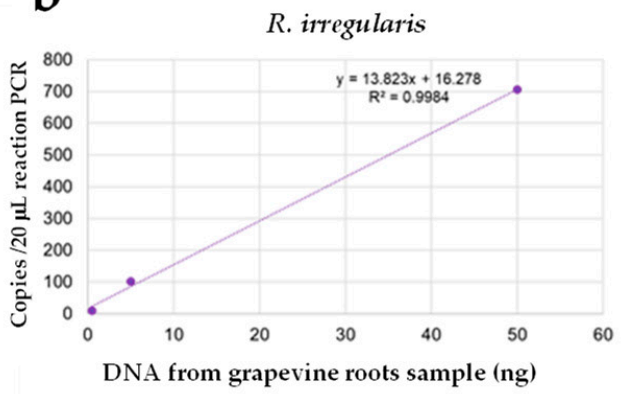

C

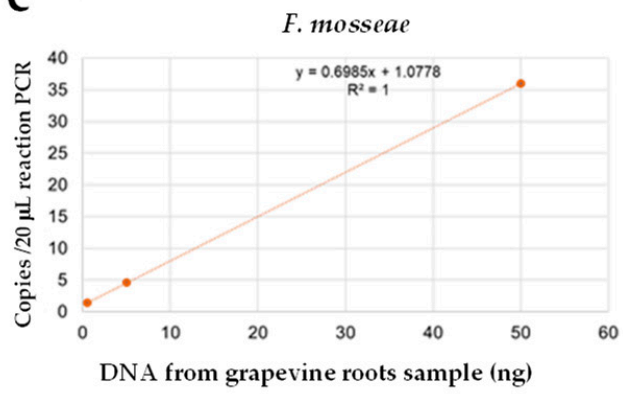

Figure 6. Several dilutions (100, 50, 5, $0.5 \mathrm{ng}$ ) of DNA from sample I10 analysed for R. irregularis and F. mosseae genes (a). The leftmost ddPCR reaction (100 ng) was saturated by an excess target concentration and the rightmost reaction contains a minimal copy of the target. The respective regression line of serial dilution was shown $(\mathbf{b}, \mathbf{c})$. C- = negative control.

Concerning Vyn_1, in esca asymptomatic plants, the abundance of F. mosseae ranged from $29.5 \pm 3.53$ copies $/ 20 \mu \mathrm{L}(20 \mu \mathrm{L}$ reaction was related to $50 \mathrm{ng}$ DNA of grapevine roots) (plant A1), to $87 \pm 4.2$ copies $/ 20 \mu \mathrm{L}$ (plant A3), while in symptomatic plants from 
$47.5 \pm 2.12$ copies $/ 20 \mu \mathrm{L}$ (I1 plant), to $157 \pm 15.5$ copies $/ 20 \mu \mathrm{L}$ (I4 plant), were detected (Figure 7a). As for R. irregularis, in the roots from esca asymptomatic plants, the quantity ranged from $49 \pm 11.3$ copies $/ 20 \mu \mathrm{L}$ (A3 plant), to $400 \pm 69.8$ copies $/ 20 \mu \mathrm{L}$ (A2 plant), while in the roots from symptomatic plants the amount ranged from $92.5 \pm 7.7$ copies $/ 20 \mu \mathrm{L}$ (I3 plant), to $358 \pm 9.9$ copies $/ 20 \mu \mathrm{L}$ (I2 plant) (Figure $7 \mathrm{~b}$ ). Overall, the average copies of $F$. mosseae gene on Vyn_1 were $49.6 \pm 4.1$ copies $/ 20 \mu \mathrm{L}$ on asymptomatic plants, and $82.8 \pm 5.1$ copies $/ 20 \mu \mathrm{L}$ on symptomatic plants, respectively, while the corresponding numbers for the $R$. irregularis gene were $188.6 \pm 22.6$ copies $/ 20 \mu \mathrm{L}$ on asymptomatic plants and $213 \pm 9.1$ copies $/ 20 \mu \mathrm{L}$ on symptomatic plants, respectively.

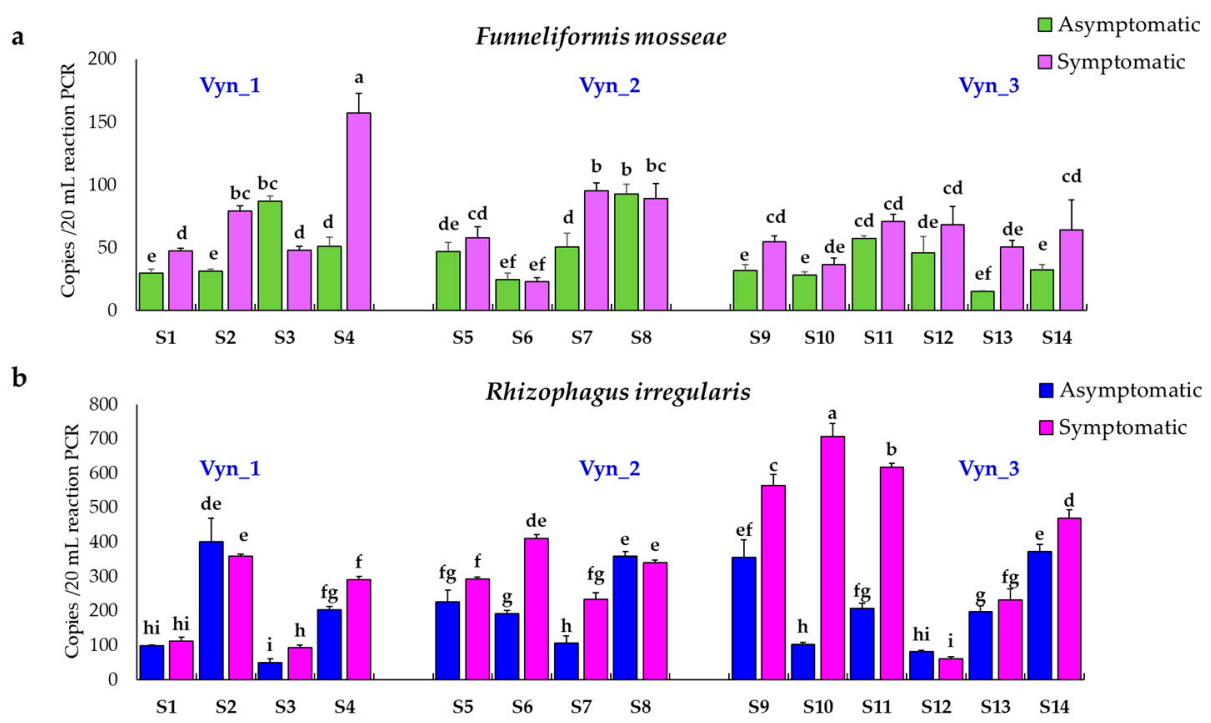

Figure 7. Amount of F. mosseae (a) and R. irregularis (b) quantified by ddPCR in each asymptomatic and contiguous esca symptomatic plants from each site (S) individuate in the vineyards (Vyn_1, Vyn_2 and Vyn_3). For each trait, means followed by at least one common letter are not significantly different, according to Duncan's Multiple Range Test $(p<0.05)$. The test was assessed on two independent experiments for each subsample $(n=4)$.

In Vyn_2, the abundance of F. mosseae ranged from $24.5 \pm 4.5$ copies $/ 20 \mu \mathrm{L}$ (A6 plant), to $92.5 \pm 7.7$ copies $/ 20 \mu \mathrm{L}$ (A8 plant), in esca asymptomatic plants, and from $22.7 \pm 3.3$ copies $/ 20 \mu \mathrm{L}$ (I6 plant), to $95.7 \pm 6.3$ copies $/ 20 \mu \mathrm{L}$ (I7 plant) in symptomatic plants (Figure 7a). Regarding R. irregularis, from $105.5 \pm 21.2$ copies $/ 20 \mu \mathrm{L}$ (A7 plant) to $358 \pm 14$ copies $/ 20 \mu \mathrm{L}$ (A8 plant), were detected in the esca asymptomatic plants, and from $233.5 \pm 19$ copies $/ 20 \mu \mathrm{L}$ (I7 plant), to $410 \pm 10.6$ copies $/ 20 \mu \mathrm{L}$ (I6 plant) in asymptomatic plants (Figure $7 \mathrm{~b}$ ). Overall, the average copies of $F$. mosseae gene on Vyn_2 was $53.6 \pm 7.6$ copies $/ 20 \mu \mathrm{L}$ on asymptomatic plants, and $66.1 \pm 7.5$ copies $/ 20 \mu \mathrm{L}$ on symptomatic plants, while about $R$. irregularis was $200.2 \pm 19.7$ copies $/ 20 \mu \mathrm{L}$ on asymptomatic plants and $319.1 \pm 10.7$ copies $/ 20 \mu \mathrm{L}$ on symptomatic plants.

In Vyn_3, the abundance of $F$. mosseae ranged from $15.3 \pm 0.3$ copies $/ 20 \mu \mathrm{L}$ (A13 plant), to $57.3 \pm 1.8$ copies $/ 20 \mu \mathrm{L}$ (A11 plant) in the esca asymptomatic plants, while it ranged from $36.5 \pm 14.8$ copies $/ 20 \mu \mathrm{L}$ (I10 plant), to $71.5 \pm 4.9$ copies $/ 20 \mu \mathrm{L}$ (I11 plant) in the symptomatic plants (Figure 7a). Regarding $R$. irregularis, in esca asymptomatic plants the abundance ranged from $81 \pm 4.24$ copies $/ 20 \mu \mathrm{L}$ (A12 plant), to $355 \pm 50.2$ copies $/ 20 \mu \mathrm{L}$, (A9 plant), while in symptomatic plants ranged from $61.5 \pm 4.9$ copies $/ 20 \mu \mathrm{L}$ (I12 plant), to $706 \pm 37.4$ copies $/ 20 \mu \mathrm{L}$ (I10 plant) (Figure $7 \mathrm{~b}$ ). Overall, the average number of copies of the $F$. mosseae gene on Vyn_3 was $37.9 \pm 4.9$ copies $/ 20 \mu \mathrm{L}$ on asymptomatic plants and $55.5 \pm 12.3$ copies $/ 20 \mu \mathrm{L}$ on symptomatic plants, while the corresponding numbers for the $R$. irregularis gene were $214.3 \pm 14.7$ copies $/ 20 \mu \mathrm{L}$ on asymptomatic plants and $345 \pm 18$ copies $/ 20 \mu \mathrm{L}$ on symptomatic plants, respectively. 


\section{Discussion}

The management of esca must be integrated with an interdisciplinary approach [1]. Since the esca pathogens often exist in soils before planting [10], the study of rhizosphere microorganisms, such as mycorrhizal fungi, could provide important information to better understand the dynamics and the light equilibrium among pathogens and beneficial communities. In this work, we analyzed the interaction among the native mycorrhizal symbiosis in both asymptomatic and esca symptomatic grapevines. Concerning the 14 sites analysed, the comprehensive approach to determine the roots mycorrhizal status by nonvital staining [52], showed the presence of mycorrhizae symbiosis in all roots analysed ( $\mathrm{F} \%$ value $=100 \%$ ), underlining the ancestral affinity of the grapevine with AMF symbiosis. However, the higher AMF colonization according to both intensity of colonization (M\%) and abundance of arbuscules (A\%) was detected in esca symptomatic plants more frequently than the neighbouring asymptomatic ones, regardless of cultivars or vineyard. This finding highlighted that esca symptomatology affected the relative amount of total AMF symbiosis in the root system. This was observed despite the high AMF abundance variability detected among the plants inside the vineyards, probably linked to the influence of soil conditions and the rhizosphere affecting AMF symbiosis establishment variability $[53,54]$. The evidence of the highest overall AMF colonization being present in esca symptomatic plants was supported by the OTUs investigation, which showed higher amounts of ITS sequences belonging to Glomeromycota phylum, which includes all AMF species [11], in the roots of symptomatic versus asymptomatic plants.

To analyze if this result was AMF species-specific, we have set up a method to quantify the native species among those commonly associated with the roots of the grapevine as $R$. irregularis and $F$. mosseae species $[26,27,55]$ using ddPCR technology. This technique showed higher sensitivity and specificity, compared to qPCR, for the diagnosis of AMF infection on root DNA, usually contaminated by high content of humic acid and root exudates, which result in PCR inhibition [56]. In our work, both R. irregularis and F. mosseae were detected in all analyzed plants. Although a great variability was found in the vineyards, the species R. irregularis is more often more present than F. mosseae. However, our data suggest higher gene copy numbers of both species in symptomatic plants than asymptomatic ones for most of all the analyzed sites or vineyards, but these numbers were not necessarily statistically significant for all cases. AMF in nature may differ in the amount of benefit they provide to hosts, but it is impossible to indicate any single partner as universally 'beneficial' or 'not beneficial' given the elevated complexity of interactions and conditions implicit in microorganism community. Our work highlights that there was no species-specific relationship among AMF and symptomatic or non-symptomatic esca plants, but that the highest amount of AMF symbiosis observed in symptomatic plants involves the whole mycorrhizal community and their rhizosphere relationship.

New studies are now required to understand what appears to be a paradox. Usually, clear relationships between root-associated fungal communities' composition and plant health status were demonstrated in several plant-mycorrhizae-pathogen interactions involving both woody perennial crops and annual crops [21,37,57-59]. Studies comparing different fungal species highlighted that the degree of protection is highly dependent on the AMF inoculated [60]. In addition, some research pointed out a higher protector effect of $F$. mosseae in comparison to other AMF species $[61,62]$. However, some studies reported higher severity of symptoms caused by viruses [35,63] or fungi disease [64], on leaves of mycorrhizal plants compared to non-mycorrhizal control plants.

Concerning grapevine trunk diseases, the inoculation of the roots with the $R$. irregularis has reduced both the number of root lesions and the severity of diseases caused by black foot disease pathogens [65]. AMF have been shown to increase tolerance of grapevine rootstocks to black foot disease caused by Ilyonectria spp., and changes in the function of the rhizosphere microbial community [31]. However, interestingly, recent greenhouse studies have shown that in the grapevine rootstocks inoculated with both I. liriodendra, a weak pathogen known for causing black foot disease, and R. irregularis AMF species, 
the amount of both AMF and pathogen were highest, unlike the results seen in control plants inoculated with one of the two. Further, the presence of the mycorrhizal fungus did not enhance the physiological parameters of the infected plants [32]. By contrast, recently, in grapevines planted in pots using soil collected from a commercial grapevine nursery, the enrichment of AMF with lowest presence of black-foot pathogens under extreme conditions of water deficit, was detected [38]. These results underline the delicate balance between inhibiting pathogens and allowing entry to beneficial fungi, in particular in esca, whose complexity lies notably in the plurality of the involved fungal pathogens, which are associated with specific symptomatology and epidemiology, from the nursery to the vineyard [66]. Similarly, direct analysis of soil-grown plants can help reveal the how this relationship changes in response to developmental, and/or biotic, and abiotic signals. Some recent work focused on trunk disease-affected vines highlighted the importance of the whole microbial community and fungal endophytes for influencing esca [67-69]. On the other hand, there is growing evidence that AMF may not be universally beneficial against pathogens, particularly in natural settings [70]. Then, the increase in mycorrhizal symbiosis on symptomatic plants is therefore not surprising, but our study emphasizes that a different relationship could be established by native AMF species compared to exogenous species. The native AMF composition is a pool of species not foreign to the rhizosphere, compared to that established by applying exogenous mycorrhizal inoculum [71]. On the other hand, it is known that both plant mutualists and pathogens share common molecular and cellular mechanisms for colonizing their hosts [72-74]. About native mycorrhizal species, the host plant and other rhizosphere organisms recognize certain organisms as their own and do not activate defense mechanisms. Then, the lack of AMF protection may be due to the relatively stress-free growing conditions among the AMF native microorganisms, which are already essential part of the plants, and the pathogens that occurred in advance in the plants. Therefore, native mycorrhizal symbiosis is useful as a bioindicator of environmental stresses [13,38]. The relationship established between the plant and native mycorrhizal species naturally present in the soil, requires a continuous exchange of signals between the host's roots and symbiont fungi $[13,14]$. Among these, an altered pattern of root exudation could affect the plant-mycorrhizae-pathogen relationship [75]. In esca symptomatic plants, wood vascular necrosis or black streaking with black gummy exudates occurs, which also acts at a distance from the place of production [76]. Other works suggest that changes in the root exudates from mycorrhizal plants are partially involved in the susceptibility of these plants to soil-borne microorganisms. Therefore, while the root exudates of mycorrhizal strawberry plants have reduced the sporulation of Phytophthora fragariae [77], the root exudates of mycorrhizal potato plants have increased the hatching of the nematodes [78]. In mycorrhizal tomato plants, the above were reported to increase the germination of Fusarium oxysporum conidia [79]. Then, this suggests that the pathogen establishment changes the relationship between the plant and all mycorrhizal symbiotes. Esca induces important changes in the root system, including a reduction in root biomass and root hairs. Although it is surprising that a greater presence of beneficial fungi is associated with plants that have reduced their vigor, this condition could further increase the need of the plant to establish mycorrhizal symbiosis useful for its nutritional needs. It is conceivable that pathogens take advantage of this symbiosis program to gain access to the host plant's resources [80]. A synergistic effect has been described among multiple pathogens when reintroduced into plants [81]. Something similar could also happen with non-pathogenic AMF. They could co-exist or even provide indirect benefits. For instance, AMF could allow to pathogens' further proliferation as a result of the increased carbon sink typical of AMF [82]. Then, several studies are necessary to understand the reason for this change in AMF community linked to esca symptoms on grapevine.

\section{Conclusions}

This investigation carried out on natural mycorrhizal state of plants affected by esca strengthens the knowledge on how the diseased plant interacts with beneficial microorgan- 
isms, modifying their concentration. In synthesis, the analysis of the AMF native symbiosis in grapevine roots showed higher levels of total mycorrhization in the symptomatic plants than in the asymptomatic plants. However, the protocol developed in this work according the ddPCR technology emphasizes that this difference is not associated with individual mycorrhizal species, but instead the entire AMF community contributes to this result.

In this work we have focused on the esca symptoms-AMF relationship in grapevine roots. The investigation of entire microbial community involved in the grapevine roots, symptomatic and asymptomatic to esca, will be able to clarify many aspects. This work contributes to a better understanding of the interactions between native AMF and the fungi related to esca, and it underlines the role of mycorrhizae as bioindicators of the soil changes taking place in the rhizosphere. These results underline that the interactions between plants and their rhizosphere microbial communities are an important point to consider for the development of strategies for the sustainable management of grapevine esca disease.

Supplementary Materials: The following are available online at https:/ / www.mdpi.com/article/10 .3390/jof7100869/s1, Supplementary Figure S1: Symptoms taken into account for the esca disease classification on Verdicchio cultivar. Leaves presented the tiger-striped pattern, with a typical yellow band between the green and necrotic tissues (left) and plant with portion of the canopy and clusters desiccated (central). On the right, canopy of a healthy plant. Supplementary Figure S2: Sequence similarity searches using NCBI Blast web site of AMF R. irregularis and F. mosseae qPCR fragments. (a), Blast alignment according 28SRNA gene of sample S1_V1 (NCBI accession number, MK513942) and S5_V3 (MK513943) showing high nucleotide similarity to R. irregularis species (HF968988.1 and FJ235574.1), (b) Blast alignment of according to LSU gene of sample S4_V1 (MK513940) and S10_V3 (MK51394) homologous to F. mosseae species (FN377862.2 and FN37865.1). Supplementary Table S1: Serial dilutions of DNA from I10 and A7 samples analyzed on qPCR for R. irregularis and F. mosseae genes. The experiments were assessed in triplicate over three independent experiments $(n=9)$. $C q$, quantification cycle; SD, standard deviation; * less of four replicates amplified of six performed; na, not amplified Supplementary Table S2: The ddPCR inhibitors investigation and LOD for AMF. Non host roots from oak plants ( 0 , and $50 \mathrm{ng} / \mathrm{qPCR}$ reaction) spiked with serial dilutions of AMF qPCR fragments (S1_V1 and S10_V3 for R. irregularis and F. mosseae, respectively) at different concentration. The test was assessed on two independent experiments $(n=2)$. Supplementary Table S3: Serial dilutions of DNA fromI10 and A7 samples analyzed on ddPCR with the primers for R. irregularis gene and LSU F. mosseae genes. The test was assessed over two independent experiments $(n=2)$. SD, standard deviation; na, not amplified.

Author Contributions: Conceptualization, L.L. and G.R.; Data curation, S.M.; Formal analysis, R.F.; Funding acquisition, G.R.; Investigation, L.L., R.F. and S.M.; Methodology, L.L. and S.M.; Project administration, G.R.; Supervision, G.R.; Writing—original draft, L.L.; Writing—review and editing, G.R. All the authors revised and approved the final manuscript. All authors have read and agreed to the published version of the manuscript.

Funding: Thanks are expressed to the project "Grapevine esca disease: understanding of epidemiology, evolution over time of symptomatic plants and evaluation of management strategies" funded by Marche Polytechnic University.

Institutional Review Board Statement: Not applicable.

Informed Consent Statement: Not applicable.

Data Availability Statement: Sequence data are available in a publicly accessible repository, as reported in the body of the paper, and in Supplementary Figure S1 and Tables S1-S3.

Acknowledgments: Thanks are expressed to the project "Understanding of epidemiology of esca disease" funded by Marche Polytechnic University. Useful discussions with colleagues that occurred at meetings helped us to clarify the presentation of our results, and they are acknowledged and appreciated.

Conflicts of Interest: The authors declare no conflict of interest. 


\section{References}

1. Gramaje, D.; Urbez-Torres, J.R.; Sosnowski, M.R. Managing grapevine trunk diseases with respect to etiology and epidemiology: Current strategies and future prospects. Plant Dis. 2018, 102, 12-39. [CrossRef]

2. Urbez-Torres, J.R. The status of Botryosphaeriaceae species infecting grapevines. Phytopathol. Mediterr. 2011, 50, S5-S45.

3. Landi, L.; Murolo, S.; Romanazzi, G. Colonization of Vitis spp. wood by sGFP-transformed Phaeomoniella chlamydospora, a tracheomycotic fungus involved in esca disease. Phytopathology 2012, 102, 290-297. [CrossRef]

4. Travadon, R.; Rolshausen, P.E.; Gubler, W.D.; Cadle-Davidson, L.; Baumgartner, K. Susceptibility of cultivated and wild Vitis spp. to wood infection by fungal trunk pathogens. Plant Dis. 2013, 97, 1529-1536. [CrossRef] [PubMed]

5. Bertsch, C.; Ramirez-Suero, M.; Magnin-Robert, M.; Larignon, P.; Chong, J.; Abou-Mansour, E.; Spagnolo, A.; Clément, C.; Fontaine, F. Grapevine trunk diseases: Complex and still poorly understood. Plant Pathol. 2013, 62, 243-265. [CrossRef]

6. Gramaje, D.; Mostert, L.; Groenewald, J.Z.; Crous, P.W. Phaeoacremonium: From esca disease to Phaeohyphomycosis. Fungal Biol. 2015, 119, 759-783. [CrossRef]

7. González-Domínguez, E.; Berlanas, C.; Gramaje, D.; Armengol, J.; Rossi, V.; Berbegal, M. Temporal dispersal patterns of Phaeomoniella chlamydospora, causal agent of petri disease and esca, in vineyards. Phytopathology 2020, 110, 1216-1225. [CrossRef] [PubMed]

8. Mugnai, L.; Graniti, A.; Surico, G. Esca (Black measles) and brown wood-streaking: Two old and elusive diseases of grapevines. Plant Dis. 1999, 83, 404-418. [CrossRef]

9. Rego, C.; Oliveira, H.; Carvalho, A.; Phillips, A. Involvement of Phaeoacremonium spp. and Cylindrocarpon destructans with grapevine decline in Portugal. Phytopathol. Mediterr. 2000, 39, 76-79. [CrossRef]

10. Berlanas, C.; Lopez-Manzanares, B.; Gramaje, D. Estimation of viable propagules of black-foot disease pathogens in grapevine cultivated soils and their relation to production systems and soil properties. Plant Soil. 2017, 417, 467-479. [CrossRef]

11. Spatafora, J.W.; Chang, Y.; Benny, G.L.; Lazarus, K.; Smith, M.E.; Berbee, M.L.; Bonito, G.; Corradi, N.; Grigoriev, I.; Gryganskyi, A.; et al. A phylum-level phylogenetic classification of zygomycete fungi based on genome-scale data. Mycologia 2016, 108, 1028-1046. [CrossRef] [PubMed]

12. Smith, S.E.; Read, D.J. Mycorrhizal Symbiosis; Academic Press: London, UK, 2008; ISBN 9780080559346.

13. Ivanov, S.; Austin, J.; Berg, R.H.; Harrison, M.J. Extensive membrane systems at the host-arbuscular mycorrhizal fungus interface. Nat. Plants 2019, 5, 194-203. [CrossRef]

14. Shi, S.; Luo, X.; Dong, X.; Qiu, Y.; Xu, C.; He, X. Arbuscular mycorrhization enhances nitrogen, phosphorus and potassium accumulation in Vicia faba by modulating soil nutrient balance under elevated $\mathrm{CO}_{2}$. J. Fungi 2021, 7, 361. [CrossRef]

15. Begum, N.; Qin, C.; Ahanger, M.A.; Raza, S.; Khan, M.I.; Ashraf, M.; Ahmed, N.; Zhang, L. Role of Arbuscular Mycorrhizal Fungi in Plant Growth Regulation: Implications in Abiotic Stress Tolerance. Front. Plant Sci. 2019, 10, 1068. [CrossRef]

16. Pozo, M.J.; Azcón-Aguilar, C. Unravelling mycorrhiza-induced resistance. Curr. Opin. Plant Biol. 2007, 10, 1-6. [CrossRef]

17. Fiorilli, V.; Vannini, C.; Ortolani, F.; Garcia-Seco, D.; Chiapello, M.; Novero, M.; Domingo, G.; Terzi, V.; Morcia, C.; Bagnaresi, P.; et al. Omics approaches revealed how arbuscular mycorrhizal symbiosis enhances yield and resistance to leaf pathogen in wheat. Sci. Rep. 2018, 8, 9625. [CrossRef]

18. Kaur, S.; Suseela, V. Unraveling arbuscular mycorrhiza-induced changes in plant primary and secondary metabolome. Metabolites 2020, 10, 335. [CrossRef] [PubMed]

19. Carretero, C.L.; Cantos, M.; Garcia, J.L.; Azcon, R.; Troncoso, A. Growth response of micropropagated cassava clones as affected by Glomus intraradices colonization. J. Plant Nutr. 2009, 32, 261-273. [CrossRef]

20. Affokpon, A.; Coyne, D.L.; Lawouin, L.; Tossou, C.; Agbèdè, R.D.; Coosemans, J. Effectiveness of native West African arbuscular mycorrhizal fungi in protecting vegetable crops against root-knot nematodes. Biol. Fertil. Soils 2011, 47, 207-217. [CrossRef]

21. Wehner, J.; Antunes, P.M.; Powell, J.R.; Caruso, T.; Rillig, M.C. Native arbuscular mycorrhizal fungal assemblages protect grassland host plants from pathogens. PLoS ONE 2011, 6, e27381. [CrossRef] [PubMed]

22. Berruti, A.; Lumini, E.; Balestrini, R.; Bianciotto, V. Arbuscular mycorrhizal fungi as natural biofertilizers: Let's benefit from past successes. Front. Microbiol. 2016, 6, 1559. [CrossRef]

23. Ceustermans, A.; Van Hemelrijck, W.; Van Campenhout, J.; Bylemans, D. Effect of Arbuscular Mycorrhizal Fungi on Pratylenchus penetrans infestation in apple seedlings under greenhouse conditions. Pathogens 2019, 7, 76. [CrossRef]

24. Verbruggen, E.; van der Heijden, M.G.A.; Weedon, J.T.; Kowalchuk, G.A.; Röling, W.F.M. Community assembly, species richness and nestedness of arbuscular mycorrhizal fungi in agricultural soils. Mol. Ecol. 2012, 21, 2341-2353. [CrossRef] [PubMed]

25. Taisuke, T.; Kobae, Y. Investigation of indigenous arbuscular mycorrhizal performance using a Lotus japonicus mycorrhizal mutant. Plants 2020, 9, 658. [CrossRef]

26. Trouvelot, S.; Bonneau, L.; Redecker, D.; van Tuinen, D.; Adrian, M.; Wipf, D. Arbuscular mycorrhiza symbiosis in viticulture: A review. Agron. Sustain. Dev. 2015, 35, 1449-1467. [CrossRef]

27. Massa, N.; Bona, E.; Novello, G.; Todeschini, V.; Boatti, L.; Mignone, F.; Gamalero, E.; Lingua, G.; Berta, G.; Cesaro, P. AMF communities associated to Vitis vinifera in an Italian vineyard subjected to integrated pest management at two different phenological stages. Sci Rep. 2020, 10, 9197. [CrossRef]

28. Schreiner, R.P.; Mihara, K. The diversity of arbuscular mycorrhizal fungi amplified from grapevine roots (Vitis vinifera L.) in Oregon vineyards is seasonally stable and influenced by soil and vine age. Mycologia 2009, 101, 599-611. [CrossRef] 
29. Balestrini, R.; Magurno, F.; Walker, C.; Lumini, E.; Bianciotto, V. Cohorts of arbuscular mycorrhizal fungi (AMF) in Vitis vinifera, a typical Mediterranean fruit crop. Environ. Microbiol. Rep. 2010, 2, 594-604. [CrossRef] [PubMed]

30. López-García, Á.; Jurado-Rivera, J.A.; Bota, J.; Cifre, J.; Baraza, E. Space and Vine Cultivar Interact to Determine the Arbuscular Mycorrhizal Fungal Community Composition. J. Fungi 2020, 6, 317. [CrossRef]

31. Jones, E.E.; Hammond, S.; Blond, C.; Brown, D.S.; Ridgway, H.J. Interaction between arbuscular mycorrhizal fungi and rootstock cultivar on the susceptibility to infection by Ilyonectria species. Phytopathol. Mediterr. 2014, 53, 582-583.

32. Holland, T.; Bowen, P.; Kokkoris, V.; Urbez-Torres, J.R.; Hart, M. Does Inoculation with Arbuscular Mycorrhizal Fungi Reduce Trunk Disease in Grapevine Rootstocks? Horticulturae 2019, 5, 61. [CrossRef]

33. Gianinazzi, S.; Gollotte, A.; Binet, M.N.; van Tuinen, D.; Redecker, D.; Wipf, D. Agroecology: The key role of arbuscular mycorrhizas in ecosystem services. Mycorrhiza 2010, 20, 519-530. [CrossRef] [PubMed]

34. Turrini, A.; Bedini, A.; Loor, M.B.; Santini, G.; Sbrana, C.; Giovannetti, M.; Avio, L. Local diversity of native arbuscular mycorrhizal symbionts differentially affects growth and nutrition of three crop plant species. Biol. Fertil. Soils 2018, 54, 203-217. [CrossRef]

35. Hao, Z.; Xie, W.; Chen, B. Arbuscular mycorrhizal symbiosis affects plant immunity to viral infection and accumulation. Viruses 2019, 11, 534. [CrossRef] [PubMed]

36. Kumar, T.; Majumdar, A.; Das, P.; Sarafis, V.; Ghose, M. Trypan blue as a fluorochrome for confocal laser scanning microscopy of arbuscular mycorrhizae in three mangroves. Biotech. Histochem. 2008, 83, 153-159. [CrossRef]

37. Binet, M.N.; Marchal, C.; Lipuma, J.; Geremia, R.A.; Bagarri, O.; Candaele, B.; Fraty, D.; David, B.; Perigon, S.; Barbreau, V.; et al Plant health status effects on arbuscular mycorrhizal fungi associatedwith Lavandulaangustifolia and Lavandula intermedia infected by Phytoplasma in France. Sci. Rep. 2020, 10, 20305. [CrossRef]

38. Carbone, M.J.; Alaniz, S.; Mondino, P.; Gelabert, M.; Eichmeier, A.; Tekielska, D.; Bujanda, R.; Gramaje, D. Drought Influences Fungal Community Dynamics in the Grapevine Rhizosphere and Root Microbiome. J. Fungi 2021, 7, 686. [CrossRef] [PubMed]

39. Hart, M.M.; Aleklett, K.; Chagnon, P.; Egan, C.; Ghignone, S.; Helgason, T.; Lekberg, Y.; Öpik, M.; Pickles, B.J.; Waller, L. Navigating the labyrinth: A guide to sequence-based, community ecology of arbuscular mycorrhizal fungi. New Phytol. 2015, 207, 235-247. [CrossRef]

40. Lekberg, Y.; Vasar, M.; Bullington, L.S.; Sepp, S.K.; Antunes, P.M.; Bunn, R.; Larkin, B.G.; Öpik, M. More bang for the buck? Can arbuscular mycorrhizal fungal communities be characterized adequately alongside other fungi using general fungal primers? New Phytol. 2018, 220, 971-976. [CrossRef]

41. Pinheiro, L.B.; Coleman, V.A.; Hindson, C.M.; Herrmann, J.; Hindson, B.J.; Bhat, S.; Emslie, K.R. Evaluation of a droplet digital polymerase chain reaction format for DNA copy number quantification. Anal. Chem. 2012, 84, 1003-1011. [CrossRef]

42. Whale, A.S.; Huggett, J.F.; Cowen, S.; Speirs, V.; Shaw, J.; Ellison, S.; Foy, C.A.; Scott, D.J. Comparison of microfluidic digital PCR and conventional quantitative PCR for measuring copy number variation. Nucleic Acids Res. 2012, 40, e82. [CrossRef] [PubMed]

43. Hayden, R.T.; Gu, Z.; Ingersoll, J.; Abdul-Ali, D.; Shi, L.; Pounds, S.; Caliendo, A.M. Comparison of droplet digital PCR to real-time PCR for quantitative detection of cytomegalovirus. J. Clin. Microbiol. 2013, 51, 540-546. [CrossRef] [PubMed]

44. Phillips, J.M.; Hayman, D.A. Improved procedures for clearing roots and staining parasitic and vesicular-arbuscular mycorrhizal fungi for rapid assessment of infection. Trans. Br. Mycol. Soc. 1970, 55, 158-161. [CrossRef]

45. Trouvelot, A.; Kough, J.L.; Gianinazzi-Pearson, V. Mesure du taux de mycorhization VA d'un système radiculaire. Recherche de méthodes d'estimation ayant une signification fonctionnelle. In Physiological and Genetical Aspects of Mycorrhizae; GianinazziPearson, V., Gianinazzi, S., Eds.; INRA Press: Paris, France, 1986; pp. 217-221. [CrossRef]

46. Doyle, J.J.; Doyle, J.L. Isolation of plant DNA from fresh tissue. Focus 1990, 12, 13-15. [CrossRef]

47. Landi, L.; Murolo, S.; Romanazzi, G. Detection of 'Candidatus Phytoplasma solani' in roots from Bois noir symptomatic and recovered grapevines. Sci. Rep. 2019, 9, 2013. [CrossRef]

48. Romanazzi, G.; Murolo, S.; Pizzichini, L.; Nardi, S. Esca in young and mature vineyards, and molecular diagnosis of the associated fungi. Eur. J. Plant Pathol. 2009, 125, 277-290. [CrossRef]

49. Toju, H.; Tanabe, A.S.; Yamamoto, S.; Sato, H. High-Coverage ITS Primers for the DNA-based identification of Ascomycetes and Basidiomycetes in environmental samples. PLoS ONE 2012, 7, e40863. [CrossRef]

50. Bustin, S.; Benes, V.; Garson, J.A.; Hellemans, J.; Huggett, J.; Kubista, M.; Mueller, R.; Nolan, T.; Pfaffl, M.W.; Shipley, G.L.; et al. The MIQE guidelines: Minimum information for publication of quantitative real time PCR experiments. Clin. Chem. 2009, 55, 611-622. [CrossRef]

51. Huggett, J.F.; Foy, C.A.; Benes, V.; Emslie, K.; Garson, J.A.; Haynes, R. The digital MIQE guidelines: Minimum information for publication of quantitative digital PCR experiments. Clin. Chem. 2013, 59, 892-902. [CrossRef]

52. Vierheilig, H.; Schweiger, P.; Brundrett, M. An overview of methods for the detection and observation of arbuscular mycorrhizal fungi in roots. Physiol. Plant 2005, 125, 393-404. [CrossRef]

53. Goh, C.H.; Veliz Vallejos, D.F.; Nicotra, A.B.; Mathesius, U. The impact of beneficial plant-associated microbes on plant phenotypic plasticity. J. Chem. Ecol. 2013, 39, 826-839. [CrossRef]

54. Nogales, A.; Santos, E.S.; Abreu, M.M.; Arán, D.; Victorino, G.; Pereira, H.S.; Lopes, C.M.; Viegas, V. Mycorrhizal inoculation differentially affects grapevine's performance in copper contaminated and non-contaminated soils. Front. Plant Sci. 2019, 9, 1906. [CrossRef]

55. Mathimaran, N.; Ruh, R.; Vullioud, P.; Frossard, E.; Jansa, J. Glomus intraradices dominates arbuscular mycorrhizal communities in a heavy textured agricultural soil. Mycorrhiza 2005, 16, 61-66. [CrossRef] 
56. Racki, N.; Dreo, T.; Gutierrez-Aguirre, I.; Blejec, A.; Ravnikar, M. Reverse transcriptase droplet digital PCR shows high resilience to PCR inhibitors from plant, soil and water samples. Plant Methods 2014, 10, 42. [CrossRef]

57. Cameron, D.D.; Neal, A.L.; van Wees, S.C.; Ton, J. Mycorrhiza-induced resistance: More than the sum of its parts? Trends Plant Sci. 2013, 18, 539-545. [CrossRef]

58. De Souza, E.M.; Granada, C.E.; Sperotto, R.A. Plant pathogens affecting the establishment of plant-symbiont interaction. Front. Plant Sci. 2016, 7, 15. [CrossRef]

59. Berdeni, D.; Cotton, T.E.A.; Daniell, T.J.; Bidartondo, M.I.; Cameron, D.D.; Evans, K.L. The effects of arbuscular mycorrhizal fungal colonisation on nutrient status, growth, productivity, and canker resistance of apple (Malus pumila). Front. Microbiol. 2018, 9, 1461. [CrossRef]

60. Kobra, N.; Jalil, K.; Youbert, G. Effects of three Glomus species as biocontrol agents against Verticillium-induced wilt in cotton. J. Plant Prot. Res. 2009, 49, 185-189. [CrossRef]

61. Utkhede, R. Increased growth and yield of hydroponically grown greenhouse tomato plants inoculated with arbuscular mycorrhizal fungi and Fusarium oxysporum f. sp. radicis-lycopersici. Biocontrol 2006, 51, 393-400. [CrossRef]

62. Ozgonen, H.; Erkilic, A. Growth enhancement and Phytophthora blight (Phytophthora capsici Leonian) control by arbuscular mycorrhizal fungal inoculation in pepper. Crop Prot. 2007, 26, 1682-1688. [CrossRef]

63. Sipahioglu, M.H.; Demir, S.; Usta, M.; Akkopru, A. Biological relationship of potato virus Y and arbuscular mycorrhizal fangus Glomus intraradices in potato. Pest Technol. 2009, 3, 63-66.

64. Liu, Y.; Feng, X.; Gao, P.; Li, Y.; Christensen, M.J.; Duan, T. Arbuscular mycorrhiza fungi increased the susceptibility of Astragalus adsugens to powdery mildew caused by Erysiphe pisi. Mycology 2018, 9, 223-232. [CrossRef] [PubMed]

65. Petit, E.; Gubler, W.D. Influence of Glomus intraradices on black foot disease caused by Cylindrocarpon macrodidymum on Vitis rupestris under controlled conditions. Plant Dis. 2006, 90, 1481-1484. [CrossRef] [PubMed]

66. Claverie, M.; Notaro, M.; Fontaine, F.; Wery, J. Current knowledge on grapevine trunk diseases with complex etiology: A systemic approach. Phytopathol. Mediterr. 2020, 59, 29-53. [CrossRef]

67. Morales-Cruz, A.; Allenbeck, G.; Figueroa-Balderas, R.; Ashworth, V.E.; Lawrence, D.P.; Travadon, R.; Smith, R.J.; Baumgartner, K.; Rolshausen, P.E.; Cantu, D. Closed-reference metatranscriptomics enables in planta profiling of putative virulence activities in the grapevine trunk disease complex. Mol. Plant Pathol. 2017, 19, 490-503. [CrossRef]

68. Alaimo, S.; Marceca, G.P.; Giugno, R.; Ferro, A.; Pulvirenti, A. Current knowledge and computational techniques for grapevine meta-omics analysis. Front. Plant Sci. 2018, 8, 2241. [CrossRef] [PubMed]

69. Almeida, A.B.; Concas, J.; Campos, M.D.; Materatski, P.; Varanda, C.; Patanita, M.; Murolo, S.; Romanazzi, G.; Félix, M.D.R. Endophytic fungi as potential biological control agents against grapevine trunk diseases in Alentejo Region. Biology 2020, 9 , 420. [CrossRef]

70. Bennett, J.A.; Maherali, H.; Reinhart, K.O.; Lekberg, Y.; Hart, M.M.; Klironomos, J. Plant-soil feedbacks and mycorrhizal type influence temperate forest population dynamics. Science 2017, 355, 181-184. [CrossRef]

71. Wehner, J.; Antunes, P.M.; Powell, J.R.; Mazukatow, J.; Rillg, M.C. Plant pathogen protection by arbuscular mycorrhizas: A role of fungal diversity? Pedobiologia 2010, 53, 197-201. [CrossRef]

72. Corradi, N.; Bonfante, P. The arbuscular mycorrhizal symbiosis: Origin and evolution of a beneficial plant infection. PLoS Pathog. 2012, 8, e1002600. [CrossRef]

73. Zamioudis, C.; Pieterse, C.M. Modulation of host immunity by beneficial microbes. Mol. Plant-Microbe Interact. 2012, 25, 139-150. [CrossRef]

74. Zhang, Y.-C.; Zou, Y.-N.; Liu, L.-P.; Wu, Q.-S. Common mycorrhizal networks activate salicylic acid defense responses of trifoliate orange (Poncirus trifoliata). J. Integr. Plant Biol. 2019, 61, 1099-1111. [CrossRef] [PubMed]

75. Badri, D.V.; Vivanco, J.M. Regulation and function of root exudates. Plant Cell Environ. 2009, 32, 666-681. [CrossRef] [PubMed]

76. Andolfi, A.; Mugnai, L.; Luque, J.; Surico, G.; Cimmino, A.; Evidente, A. Phytotoxins produced by fungi associated with grapevine trunk diseases. Toxins 2011, 3, 1569-1605. [CrossRef] [PubMed]

77. Norman, J.R.; Hooker, J.E. Sporulation of Phytophthora fragariae shows greater stimulation by exudates of non-mycorrhizal than by mycorrhizal strawberry roots. Mycol. Res. 2000, 104, 1069-1073. [CrossRef]

78. Ryan, A.; Jones, P. The effect of mycorrhization of potato roots on the hatching chemicals active towards the potato cyst nematodes, Globodera pallida and G. rostochiensis. Nematology 2004, 6, 335-342. [CrossRef]

79. Singh, P.K.; Mishra, M.; Vyas, D. Effect of root exudates of mycorrhizal tomato plants on microconidia germination of Fusarium oxysporum f. sp. lycopersici. Arch. Phytopathol. Plant Prot. 2010, 43, 1495-1503. [CrossRef]

80. Rey, T.; Schornack, S. Interactions of beneficial and detrimental root-colonizing filamentous microbes with plant hosts. Genome Biol. 2013, 14, 121. [CrossRef]

81. Lamichhane, J.R.; Venturi, V. Synergisms between microbial pathogens in disease complexes: A growing trend. Front. Plant Sci. 2015, 6, 385. [CrossRef]

82. Staddon, P.L.; Fitter, A.H.; Robinson, D. Effects of mycorrhizal colonization and elevate atmospheric carbon dioxide on carbon fixation and below-ground carbon partitioning in Plantago lanceolata. J. Exp. Bot. 1999, 50, 853-860. [CrossRef] 